\title{
Analisis Penulisan Abstrak Bahasa Inggris pada Karya Tulis Ilmiah Mahasiswa D3 RMIK STIKes Mitra Husada Karanganyar
}

\author{
Erna Adita Kusumawati ${ }^{1}$, Sri Sugiarsi ${ }^{2}$ \\ 1,2 Program Studi Sarjana Terapan Manajemen Informasi Kesehatan \\ STIKes Mitra Husada Karanganyar \\ Email: ${ }^{1}$ ernaadita@gmail.com ${ }^{2}$ sri sugiarsi@yahoo.com
}

\begin{abstract}
Based on the preliminary survey that had been done toward ten English abstracts of Medical Record students graduated on 2018, it was still found a lot of mistakes in the writing (tenses). This research was aimed at identifying the use of tenses in sentences applied in the English abstract of Medical Record students in STIKes Mitra Husada Karanganyar. The type of this research was descriptive through documentation study approach. The population was all English abstracts of scientific writing of Medical Record students graduaten in 2018 which was 120. The sampling was purposive sampling. The data were analyzed descriptively. The results of the research showed that the inappropriate use of tense was more than that of the appropriate one in the part of background; the inappropriate use of tense was more than that of the appropriate one in the part of research method; the inappropriate use of tense was more than that of the appropriate one in the part of result (findings); the appropriate use of tense was more than that of the inappropriate one in the part of discussion; and the appropriate use of tense was more than that of the inappropriate one in the part of conclusion and suggestion
\end{abstract} Keywords: abstract, appropriate, inappropriate, tense, use

\begin{abstract}
Abstrak
Menurut hasil survei yang telah dilakukan terhadap 10 abstrak bahasa Inggris mahasiswa RMIK tahun kelulusan 2018, masih ditemukan banyak kesalahan dalam penulisan kalimat (tenses). Tujuan penelitian adalah mengidentifikasi penggunaan tipe kalimat (tenses) yang digunakan pada abstrak bahasa Inggris mahasiswa D3 Rekam Medis dan Informasi Kesehatan STIKes Mitra Husada. Jenis penelitian adalah desriptif dengan pendekatan studi dokumen. Populasinya adalah seluruh abstrak berbahasa Inggris pada karya tulis ilmiah mahasiswa D3 Rekam Medis dan Informasi Kesehatan STIKes Mitra Husada Karanganyar telah lulus tahun 2018 yang berjumlah 120. Teknik pengambilan sampel dengan purposive sampling. Analisis penelitian dilakukan secara deskriptif. Hasil penelitian menunjukkan bahwa penggunaan tenses yang tidak tepat lebih banyak dilakukan di pendahuluan abstrak pada bagian latar belakang; penggunaan tense yang tidak tepat lebih banyak dilakukan daripada penggunaan tense yang tepat pada bagian metodologi penelitian; penggunaan tense yang tidak tepat lebih banyak dilakukan daripada penggunaan tense yang tepat pada bagian hasil penelitian (temuan); penggunaan tense yang tepat lebih banyak dilakukan daripada penggunaan tense yang tidak tepat pada bagian pembahasan (diskusi); dan penggunaan tense yang tepat lebih banyak dilakukan daripada penggunaan tense yang tidak tepat pada bagian kesimpulan dan saran
\end{abstract}

Kata Kunci: abstrak, penggunaan, tense, tepat, tidak tepat

\section{PENDAHULUAN}

Salah satu kewajiban bagi mahasiswa sebagai persyaratan kelulusan adalah membuat karya tulis ilmiah. Karya tulis ilmiah adalah karya tulis yang disusun secara sistematis menurut aturan atau kaidah tertentu berdasarkan hasil berpikir ilmiah. Karya ilmiah terbagi atas beberapa jenis, yaitu laporan penelitian, makalah, karya tulis ilmiah, skripsi, tesis, disertasi dan proposal (Jauhari, 2010). Salah satu unsur yang penting dalam karya tulis ilmiah adalah abstrak. Hal tersebut dikarenakan abstrak merupakan hasil ringkasan yang memuat intisari karya ilmiah. Abstrak juga menjadi tolak ukur terhadap isi dari karya ilmiah tersebut. Pembaca akan tertarik atau tidak untuk membaca karya ilmiah juga ditentukan oleh abstrak tersebut. 
Abstrak diletakkan di halaman awal sebuah karya tulis dengan tujuan untuk membantu pembaca agar dapat dengan mudah dan cepat melihat tujuan dan penulisannya (Polontalo, 2013). Abstrak merupakan deskripsi singkat dari suatu karya tulis ilmiah yang mencakup latar belakang, masalah yang diteliti, metode yang digunakan, hasil-hasil yang diperoleh, kesimpulan, dan saran yang diajukan.

Seiring dengan perkembangan zaman, abstrak penelitian ilmiah dibuat dalam dua bahasa, yaitu bahasa Indonesia dan bahasa Inggris. Penulisan abstrak bebahasa Inggris merupakan respon dari kemajuan ilmu pengetahuan dan teknologi dimana karya-karya ilmiah dipublikasikan lewat internet sehingga karya-karya ilmiah tersebut dapat diakses secara global. Oleh sebab itu, penerjemahan abstrak dari bahasa Indonesia ke dalam bahasa Inggris menjadi hal yang sangat krusial. Penulisan abstrak dalam versi bahasa Inggris harus ditulis dengan memenuhi kaidah penulisan Bahasa Inggris yang baik dan benar, dalam hal ini harus ditulis dengan tipe kalimat (tenses) yang sesuai. Menurut hasil survey yang telah dilakukan terhadap 10 abstrak mahasiswa RMIK tahun kelulusan 2018, masih ditemukan banyak kesalahan dalam penulisan kalimat (tenses) pada bagian pendahuluan abstrak. Hal ini dikarenakan sebagian besar mahasiswa menerjemahkan abstrak dari bahasa Indonesia kedalam bahasa Inggris secara kata per kata (word by word). Ini tidak sesuai dengan kaidah-kaidah dalam menerjemahkan.

Menerjemahkan adalah suatu tindakan mentransfer teks dari bahasa asal (source language) kedalam bahasa yang diinginkan (target language) dalam suatu konteks tertentu (Foster, 1958). Menerjemahkan merupakan suatu proses dan metode yang digunakan untuk menyampaikan makna dari bahasa asal kedalam bahasa yang diinginkan. Dengan kata lain, dalam menerjemahkan lebih difokuskan pada gagasan tentang makna sebagai elemen penting (Ghazala, 1995). Itulah mengapa ketika kita menerjemahkan berarti kita sedang memahami makna dari bahasa asal dan mentransfernya ke bahasa yang diinginkan sesuai dengan tata bahasa yang baik dan benar (meaning to meaning).

Berdasarkan hal tersebut maka perlu dilaksanakan penelitian dengan judul "Analisis Penulisan Abstrak Bahasa Inggris pada Karya Tulis Ilmiah Mahasiswa D3 Rekam Medis dan Informasi Kesehatan STIKes Mitra Husada Karanganyar".

\section{METODE}

Jenis rancangan penelitian ini adalah observasional dengan pendekatan deskriptif. Maksudnya adalah pengumpulan data melalui observasi terhadap dokumen karya tulis ilmiah dengan tujuan mendisripsikan kesesuaian penulisan pendahuluan abstrak dalam bahasa Inggris. Populasi dalam penelitian ini adalah seluruh abstrak berbahasa inggris pada karya tulis ilmiah mahasiswa D3 Rekam Medis dan Informasi Kesehatan STIKes Mitra Husada Karanganyar telah lulus tahun 2018 yang berjumlah 120 . Teknik pengambilan sampel dengan purposive sampling dan diperoleh sampel sebanyak 30 abstrak dari karya tulis ilmiah. Pengumpulan data dilakukan melalui studi dokumen dengan menggunakan cheklist. Analisis data dalam penelitian ini adalah diskriptif yaitu memberikan deskripsi mengenai bagian pendahuluan abstrak bahasa Inggris mahasiswa D3 RMIK STIKes Mitra Husada Karanganyar dalam kaitannya dengan tenses yang digunakan pada bagian pendahuluan abstrak.

\section{HASIL}

Tabel 1. Analisis Penggunaan Tenses pada Abstrak Bahasa Inggris Karya Tulis IImiah Mahasiswa D3 Rekam Medis dan Informasi Kesehatan STIKes Mitra Husada Karanganyar

\begin{tabular}{lcc}
\hline Komponen & $\begin{array}{c}\text { Tepat } \\
\mathbf{n}(\%)\end{array}$ & $\begin{array}{c}\text { Tidak Tepat } \\
\mathbf{n}(\%)\end{array}$ \\
\hline Pendahuluan & $14(46,7 \%)$ & $16(53,3 \%)$ \\
Metode & $11(36,7 \%)$ & $19(63,3 \%)$ \\
Hasil & $14(46,7 \%)$ & $16(53,3 \%)$ \\
Simpulan & $20(66,7 \%)$ & $10(33,3 \%)$ \\
n(sampel) & 30 & \\
\hline
\end{tabular}

Tabel 1 menunjukkan bahwa penggunaan tenses tidak tepat tertinggi terdapat pada komponen metode penelitian sebanyak 19(63,3\%) abstrak pada artikel penelitian. Kesalahan tersebut terletak pada penggunaan Present Tense.

Kesalahan penggunaan tenses tertinggi berikutnya adalah pada pendahuluan abstrak; yaitu penggunaan teses Simple Present Tense untuk merujuk pada survei pendahuluan yang telah dilakukan; sebanyak 16(53,3\%). Demikian pula kesalahan penggunaan tesis terjadi pada penulisan hasil penelitian; yaitu penggunaan Simple Present Tense. Sebagian besar 
penggunaan tenses pada penulisan simpulan abstark sudah tepat; 20(66,6\%) yaitu penggunaan Simple Past Tense) . dan yang tidak tepat; 10(33,3\%); Simple Present Tense.

\section{PEMBAHASAN}

Berdasarkan deskripsi dan analisis data abstrak bahasa Inggris Karya Tulis Ilmiah mahasiswa D3 Rekam Medis dan Informasi Kesehatan STIKes Mitra Husada Karanganyar, diperoleh gambaran kesalahan pada penggunaan tenses yang terdapat pada pendahuluan, metode penelitian, hasil (temuan), pembahasan (diskusi), simpulan, dan saran.

\section{Pendahuluan}

Temuan pertama pada penelitian ini adalah penggunaan tenses pada bagian pendahuluan pada sebuah abstrak bahasa Inggris yang meliputi Tepat (T) dan Tidak Tepat (TT). Penggunaan tenses yang tepat pada bagian pendahuluan yaitu sebanyak 14 abstrak (46,6\%). Penggunaan tenses yang tepat pada pendahuluan yaitu menggunakan Simple Past Tense untuk menjelaskan apa yang sudah dilakukan peneliti dalam penelitiannya (dalam hal ini adalah survei yang sudah dilakukan peneliti): "Preliminary survey results at Army Hospital dr. Soedjono Magelang found that there were differences in reporting ..." Kata found dan there were merujuk pada bentuk Simple Past Tense yang digunakan untuk menyatakan kejadian yang sudah dilakukan sebelumnya (lampau).

Sedangkan terdapat 16 abstrak (53,3\%) yang penggunaan tenses nya tidak tepat, yaitu dengan menggunakan Simple Present Tense untuk merujuk pada survei pendahuluan yang telah dilakukan: "Patient satisfaction at RSUD dr. Soediran Mangun Sumarso Wonogiri shows that ..." Kata shows menunjukkan Simple Present Tense yang merujuk pada kegiatan survei yang telah dilakukan oleh peneliti. Penggunaan shows pada kalimat tersebut tidak tepat karena survei dilakukan oleh peneliti pada suatu waktu sebelum penelitian dilakukan, sehingga kata yang tepat untuk menggantikan shows adalah showed, yang merupakan bentuk lampau (Verb 2) dari show. Jadi kalimat yang benar seharusnya "Patient satisfaction at RSUD dr. Soediran Mangun Sumarso Wonogiri showed that ...."

Adapun Simple Present Tense yang digunakan pada bagian pendahuluan hanya sebatas untuk menunjukkan fakta dan kebenaran dai informasi yang kita terima dan masih relevan sampai saat ini dan dinilai benar: "Professional Ethics is a dicipline that accesses and learns about the good of bad behavior, attitude of human being". Penggunaan is pada kalimat tersebut sudah tepat karena Etika Profesi merupakan kebenaran atau fakta umum yang tidak berubah dari dulu sampai sekarang.

\section{Metode}

Temuan kedua dalam penelitian ini adalah penggunaan tenses pada bagian metode penelitian. Penggunaan tenses yang tepat ditemukan dalam abstrak karya tulis ilmiah mahasiswa D3 Rekam Medis dan Informasi Kesehatan STIKes Mitra Husada Karanganyar sebanyak 11 abstrak (36,6\%). Tenses yang tepat pada bagian metode penelitian adalah Simple Past Tense: "The population in this study were the whole new outpatients at ..." dan "The instruments used a checklist and guidelines of unstructured interview". Kata were dan used menunjukkan bentuk Simple Past Tense dimana were adalah to be Past Tense sedangkan used merupakan bentuk lampau (Verb 2) dari kata use, yang artinya menggunakan. Penggunaan were dan used sudah tepat karena bentuk Past Tense pada bagian metode dalam abstrak menjelaskan apa yang telah dilakukan peneliti terkait dengan pendekatan penelitian yang diimplementasikan.

Terdapat pula 19 abstrak (63,3\%) yang penggunaan tenses nya tidak tepat: "This study uses a crosssectional approach." dan "The instrument in this research is questionnaire". Pada kalimat tersebut menunjukkan kegiatan yang dilakukan peneliti termasuk pendekatan penelitian yang dilakukan, maka penggunaan uses dan is (Present Tense) tidak tepat. Seharusnya kalimat tersebut menggunakan Simple Past Tense sehingga kalimat yang tepat adalah "This study used a cross-sectional approach." dan "The instrument in this research was questionnaire". Adapun penggunaan Simple Present Tense pada bagian metode penelitian hanya sebatas untuk menunjukkan prosedur dan kegiatan standar dalam penelitian.

\section{Hasil}

Temuan ketiga adalah penggunaan tenses pada bagian hasil atau temuan pada abstrak. Penggunaan tenses yang tepat ditemukan dalam abstrak karya tulis ilmiah mahasiswa D3 Rekam Medis dan Informasi Kesehatan STIKes Mitra Husada Karanganyar sebanyak 14 abstrak (46,6\%). Simple Past Tense digunakan pada bagian hasil atau temuan: "The 
result showed that inter-table distance analyzing ..."; "The results showed the completeness of the medical records..."; dan "The result showed that the management statistical data resources for ...". Penggunaan kata showed dalam kalimat tersebut sudah tepat karena showed merupakan bentuk lampau (Verb 2) yang berasal dari kata dasar (Verb 1) show yang berarti menunjukkan.

Sementara itu terdapat 16 abstrak $(53,3 \%)$ dengan penggunaan tense yang tidak tepat yaitu dengan menggunakan Simple Present Tense untuk menyatakan hasil temuan: "The result of research shows that the return flow of inpatient medical record document has been executed ..."; "The result of research shows that temperature and humidity still above standard ..."; dan "The result of research shows that most of patient knowledge on authority medical information is ....". Pada ketiga kalimat tersebut terdapat kata shows yang menunjukkan penggunaan Simple Present Tense pada bagian hasil temuan. Kata shows dalam konteks tersebut tidak tepat karena mengacu pada suatu hasil dari kegiatan yang sudah dilakukan pada masa lampau. Kata show seharusnya ditulis menjadi showed (Simple Past Tense) yang merujuk pada kegiatan yang lampau, sehingga kalimat tersebut menjadi "The result of research showed that the return flow of inpatient medical record document has been executed ..."; "The result of research showsed that temperature and humidity still above standard ..."; dan "The result of research showed that most of patient knowledge on authority medical information is ....".

\section{Kesimpulan dan Saran}

Temuan kelima adalah penggunaan tense pada bagian kesimpulan dan saran. Terdapat 6 abstrak dimana dalam penulisannya tidak mencantumkan kesimpulan dan saran. Penggunaan tense yang tepat pada bagian kesimpulan dan saran sebanyak 20 abstrak (83,3\%): "The conclusion of the study was that the management of risk in the Boyolali RSU filing unit had not been carried out yet risk grading." dan "The suggestion in this study is that it is better to conduct socialization or training to ...." Penggunaan was (Simple Past Tense) pada bagian kesimpulan sebuah abstrak sudah tepat karena merujuk pada intisari, ringkasan dan implikasi temuan. Sedangkan penggunaan is (Simple Present Tense) pada bagian saran juga sudah tepat karena untuk menyatakan sesuatu yang umum, yang pada kenyataannya bisa dilaksanakan atau tidak.
Sementara itu terdapat $4(16,6 \%)$ abstrak yang penggunaan tense nya tidak tepat pada bagian kesimpulan dan saran: "The conclusions of this study are that no expedition book is available for submission of incomplete medical record documents." dan "Advisable, held socialization about borrowing medical record document for research and law which appropriate with procedure operational standard which had set by the head of ....." Penggunaan are dan is (Simple Present Tense) untuk menyatakan kesimpulan dinilai tidak tepat karena merujuk pada intisari, ringkasan dan implikasi temuan, yang seharusnya menggunakan Simple Past Tense sehingga kalimatnya berubah menjadi "The conclusions of this study were that no expedition book was available for submission of incomplete medical record documents." Sedangkan penggunaan held dan had set (Simple Past Tense) pada bagian saran juga tidak tepat karena untuk menyatakan sesuatu yang umum, yang pada kenyataannya bisa dilaksanakan atau tidak, sehingga lebih tepat menggunakan Simple Present Tense: "Advisable, hold socialization about borrowing medical record document for research and law which appropriate with procedure operational standard which is set by the head of ....."

\section{SIMPULAN}

Berdasarkan paparan data dan temuan penelitian dapat dikemukakan beberapa simpulan. Kesalahan penggunaan tense pada abstrak bahasa Inggris pada karya tulis ilmiah mahasiswa D3 Rekam Medis dan Informasi Kesehatan STIKes Mitra Husada Karanganyar terdiri atas penggunaan tense yang tepat dan tidak tepat. Penggunaan tense yang tidak tepat lebih banyak dilakukan daripada penggunaan tense yang tepat, yaitu pada bagian pendahuluan, metode penelitian, dan hasil (temuan) penelitian. Sedangkan penggunaan tense yang tepat terdapat pada bagian pembahasan (diskusi) serta kesimpulan dan saran.

\section{DAFTAR PUSTAKA}

Al-Khasawneh, F. M. (2017). A Genre Analysis of Research Article Abstracts Written by Native and Non-Natve Speakers of English. Journal of Applied Linguistics and Language Research, 4 (1): 1-13.

Arikunto, Suharsimi. (2006). Prosedur Penelitian Suatu Pendekatan Praktik (pp 47-49). Jakarta, Indonesia 
Behnam, B \& Golpour, F. (2014). A Genre Analysis of English and Iranian Research Article Abstracts in Applied Linguistics and Mathematics. International Journal of Applied Linguistics and Literature, 3 (5): 173-179.

Darabad, A. M. (2016). Move Analysis of Research Article Abstracts: A Cross-Disciplinary Study. International Journal of Linguistics, 8 (2):125-140.

Doro, K. (2013). The Rhetoric Structure of Research Article Abstracts in English Studies Journal. Prague Journal of English Studies, 2 (1):119-139.

Foster, C.R. (1958). Social Research: An International Quarterly (pp108-12). New York, USA

Ghasempour, B \& Farnia, M. (2017). Contrastive Move Analysis: Persian and English Research Articles Abstracts in Law. The Journal of Teaching English for Specific and Academic Purposes, 5 (4): 739-753

Indarto, Wusono. (2012). Analisis Karya Tulis (Skripsi) Tugas Akhir Mahasiswa Program Studi Administrasi Pendidikan Periode 2008/2009 dan 2009/2010. Educhild: Jurnal Pendidikan Sosial dan Budaya, 1(1): 70-78

Jackson, S.L. 2009. Research methods and Statistcs: A Critical Thinking Approach 3rd edition. Belmont: Wadsworth

Jauhari, Heri. 2010. Pedoman Penulisan Karya Ilmiah. Bandung: CV Pustaka Setia

Koopman, Philip. 2001. How to Write an Abstract. London: Facet
Leki, I. 1998. Academic Writing. Cambridge: Cambridge University Hairston

Loutayf, Maria Soledad. (2017). Analysis of abstracts in English: A study of abstracts written by EFL writers in Argentina. Argentinian Journal of Applied Linguistics, 5(1): 15-36

Mohamadzadeh, Shirin. (2013). Genre Analysis of Literature Research Article Abstracts: A Cross-Linguistic, Cross-cultural Study. Journal of Applied Research on English Language, 2(2): 37-50

Rahmiati. (2015). Analisis Kendala Internal Mahasiswa dalam Menulis Karya Ilmiah. Jurnal Al-daulah, 4(2): 327-343

Rismen, Safna. (2015). Analisis Kesulitan Mahasiswa dalam Penyelesaian Skripsi di Prodi Pendidikan Matematika STKIP PGRI. LEMMA, 1(2): 57-62.

Supatranonta, Pisamai. (2012). Developing a Writing Template of Research Article Abstracts: A Corpus-based Method. Procedia - Social and Behavioral Sciences, 66 (2012): 144-156.

Terzi, Canan \& Arslanturk, Yalcin. (2014). An Analysis of Dissertation Abstracts In Terms Of Translation Errors and Academic Discourse. International Journal of English Language and Translation Studies, 2(4): 1-11.

Zhen-ye, Ning. (2008). A Genre-based Analysis of English Research Article Abstracts and the Linguistic Feature of Personal Pronouns for Financial Economics. US-China Education Review, 5(7): 62-65. 